\title{
Effect of different irrigation intervals on growth and yield of chilli crop grown in sandy soil
}

\author{
M.S. Fathima Sahana and M. Sugirtharan* \\ Department of Agricultural Engineering, Faculty of Agriculture, Eastern University, Sri Lanka
}

\begin{abstract}
A study was carried out to evaluate the effect of different irrigation intervals on growth and yield performance of chilli grown under dry weather condition in sandy soil of Batticaloa district. The experimental setup was a Randomized Complete Block Design of four treatments and five replicates. The treatments applied were; T1 (irrigated daily as control), T2 (at 3 days irrigation interval), T3 (at 5 days interval for first 12 weeks and then with 6 days interval) and T4 (at 7 days irrigation interval). Growth and yield attributes such as plant height, leaf area, number of branches, fresh and dry weight of plant shoots and roots and yield were recorded. The results revealed that, higher irrigation frequency had shown higher growth rate on crop characteristics such as plant height $(64.3 \mathrm{~cm})$, leaf area $\left(28.48 \mathrm{~cm}^{2}\right)$, shoot fresh weight $(112.09 \mathrm{~g})$, shoot dry weight $(28.01 \mathrm{~g})$, root fresh weight $(12.58 \mathrm{~g})$, root dry weight $(3.85 \mathrm{~g})$ etc. Further, the daily irrigation significantly increased the yield of chilli, whereas irrigation at 3 days and 5 days did not influence significantly. The yield was significantly lower for treatment with 7 days irrigation interval. The yield reduction was by $45.4 \%$ for 7 days irrigation interval from daily irrigated plots which was significantly higher. Study concluded that, daily irrigation shows highest desirable output for most of the parameters. Non-significant differences in growth characteristics were noticed for the T2 and T3, while 7 days irrigation interval (T4) shows the lowest performance on the growth characteristics of chilli. Therefore, daily irrigation is most suitable for sandy soils under dry weather conditions in this study area.
\end{abstract}

Keywords: Chilli, Dry weight, Irrigation interval, Leaf area, Yield

\section{INTRODUCTION}

Among the several constraints of crop production identified, decreased water availability is the major problems in the dry zone area (Udagedara and Sugirtharan 2018) and, it is to be done in more efficient and well-organized manner. Therefore, two issues that need attention are 1) finding means of lowering the existing level of water demand by some efficient water use techniques, and 2) promote economic return to the farmers to enhance economic incentives. These can be achieved through increased water productivity and crop diversification with high value crops in the cropping systems (Adhikari and Shakya, 1995).

Many countries of the world have become extremely vulnerable to the impacts of climate change (Rakha et al., 2018). The scarcity of water is a serious fright for food security of these countries and climate change has aggravated the risks of extreme disasters like drought (Dorji et al., 2005; Juan et al., 2018). Water scarcity is a major issue for irrigation in the world (Arulkirithas et al., 2019) especially in developing countries, therefore, the global population realized that efficient water use is crucial for sustainable water management (Kei et al., 2008). Under water demand management most attention has been given to irrigation scheduling,

\footnotetext{
*Corresponding author: sugirtharan818@yahoo.com

Received: 06.05.2020

D https://orcid.org/0000-0003-0715-1429

Accepted: 09.04.2021
} 
giving slight role to irrigation methods. Many parameters like crop growth stage and its sensitivity to water stress, and water availability in the soil determine when to irrigate or the irrigation frequency. However, this frequency is influenced by the irrigation method and therefore, both irrigation scheduling and the irrigation method are inter-related (Konstantinos and Maria 2015). Effectively irrigating a specific crop in a specific soil requires the development of a good irrigation schedule. An effective irrigation schedule helps to maximize profit while minimizing water and energy use (Robert et al., 1996). At present, it is necessary to improve vegetable production and derive ways through which maximum benefits can be obtained from the limited available water resources (Mateen et al., 2005).

Chilli crop is popular and grown in many parts of the Batticaloa district without consideration of the water requirement and irrigation scheduling. Irrigation is essential for chilli cultivation in this region where there is little or no rainfall during the growing season. Therefore, it is important to identify the appropriate irrigation requirement of the crop with exact irrigation interval for the purpose of efficient water utilization and better production of the crop. In this view, the present study was conducted to evaluate the effect of different irrigation intervals on growth performance of chilli grown under dry weather condition in sandy soil of Batticaloa district.

\section{MATERIALS AND METHODS}

\section{Study location}

The experiment was carried out during the period of March to June 2019 at Vantharumoolai, Batticaloa, Sri Lanka which belongs to the agro climatic region of low country dry zone of Sri Lanka. It receives mean annual rainfall ranges from $1400 \mathrm{~mm}$ to $1680 \mathrm{~mm}$ and temperature varies from $26^{\circ} \mathrm{C}$ to $36^{0} \mathrm{C}$.

\section{Experimental Design and Treatment}

The experiment was laid out in a randomized complete block design (RCBD) with four irrigation intervals (Table 1), and five replicate blocks. Each experimental plot was $1.8 \mathrm{~m}^{2}(1.5 \mathrm{~m} \times 1.2 \mathrm{~m})$ in size, with nine plants per plot (Figure 1). The plots were prepared as raised beds in order to avoid lateral movement of water.

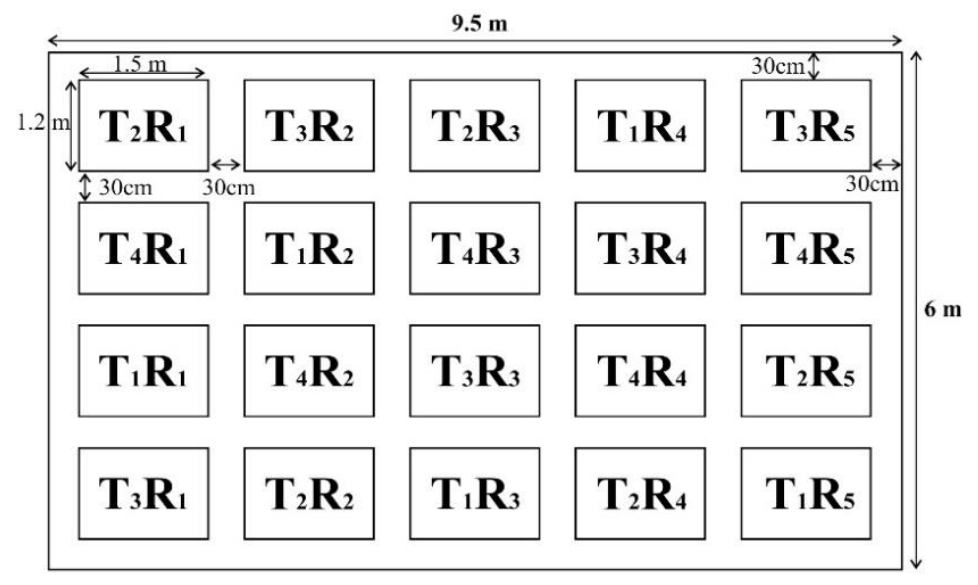

Figure 1: RCBD arrangement of the experimental plots 
Table 1: Treatments details

\begin{tabular}{ll}
\hline Treatment code & Irrigation intervals \\
\hline T1 & Control (irrigating daily) \\
T2 & Irrigation at 3 days interval \\
T3 & Irrigation at 5 days interval for first 9weeks, at 6 days interval \\
& for last 3 weeks (calculated irrigation interval) \\
T4 & Irrigation at 7 days interval \\
\hline
\end{tabular}

\section{Determination of soil characteristics and irrigation components}

Soil core sample method was used to determine the bulk density of the soil. Soil texture was analysed using hydrometer method and texture class was determined using USDA texture triangle. Field capacity (FC) and permanent wilting point (PWP) was determined using field method and gravimetric water content method.

Evapotranspiration was measured using Class A Evaporation pan with a pan coefficient of 0.55. Management Allowable Deficit (MAD) was assumed to be $50 \%$ (Amend, 2005) and root zone depth of $45 \mathrm{~cm}$ was considered for chilli (in order to calculate the Net Irrigation Requirement (NIR).

\section{Field transplantation and Agronomic management}

Chilli PC-1 variety seedlings at the stage of 42 days after sowing were transplanted in the field at the spacing of $60 \mathrm{~cm} \times 45 \mathrm{~cm}$ with 2 plants per hole and thinned out after 2 weeks of transplanting leaving one plant per hole. The seedlings were irrigated daily for first 2 weeks to ensure their successful establishment in the field and then they were irrigated according to the treatments. Agronomic practices and other cultural practices required for crop growth such as, weeding, fertilizer application, pest and disease control etc. were carried out based on the recommendation of DOA, Sri Lanka (2019) for chilli cultivation.

\section{Measurement of growth and yield attributes}

Growth parameters such as plant height, number of branches/plant and leaf area were recorded at 15, 30, 4560 , and 75 days after transplanting (DATP). Fresh weight of roots and shoots, dry weight of roots and shoots were measured at 75 days after transplanting.

Finally, yield was taken from all treatments. Plants were selected randomly from each replicate of each treatment for the measurement and recording purposes. Similarly, number of plants planted and the number of plants remained alive at each treatment were also taken in order to calculate the survival percentage.

\section{Statistical analysis}

All the collected data were subjected to analysis of variance (ANOVA) using statistical software SPSS version 22. The means were separated and then compared using Duncan's multiple range test at 5\% probability. 


\section{RESULTS AND DISCUSSION}

\section{Soil characteristics and irrigation components}

Soil texture was determined before planting and found sand, silt and clay fractions as $92.9 \%, 1.1 \%$ and $6.0 \%$ respectively. Based on the USDA soil texture triangle, the soil is sandy in nature. And the bulk density was determined as $1.75 \mathrm{~g} / \mathrm{cm}^{3}$. The field capacity, permanent wilting point and evapotranspiration were calculated as $10.6 \%, 5.5 \%$ and $4 \mathrm{~mm} /$ day respectively. Calculated FC, PWP, Bulk density, Root zone depth and MAD value of the field was used to compute the Net irrigation requirement as $2.01 \mathrm{~cm}$.

\section{Irrigation scheduling}

Crop evapotranspiration was calculated with the evaporation pan reading and crop coefficient values. The reference evapotranspiration of the experimental area (ETo) was calculated as $4.0 \mathrm{~mm} /$ day. Based on the ETo and $\mathrm{K}_{\mathrm{C}}$ value of the chilli crop, the crop evapotranspiration for the first 9 weeks and the last 3 weeks was found as 4.2 $\mathrm{mm} /$ day and $3.6 \mathrm{~mm} /$ day respectively. Accordingly, the irrigation interval for the first 9 weeks and the last 3 weeks are determined as 5 days and 6 days respectively. The irrigation period for one plot is calculated as 1.695 minutes using hose pipe. Thus, all the treatment plots were irrigated for 1.7 minutes.

\section{Growth performance of chilli under different irrigation intervals}

\section{Plant height}

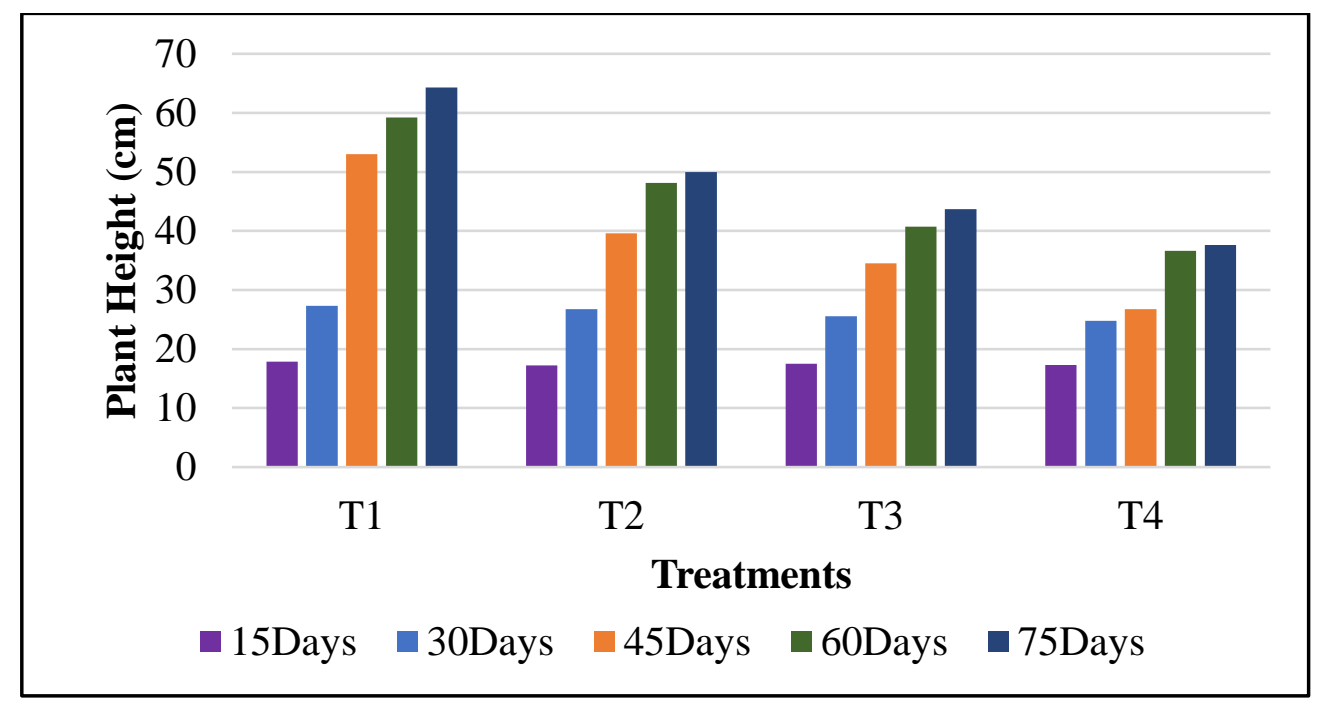

Figure 2: Effect of different irrigation intervals on mean plant height at different growth stages of chilli (PC-1)

A comparable difference in plant height during the growth stages was obtained from 30 DATP (days after transplanting) to 60 DATP. According to the results the maximum plant height was observed at control (daily irrigation - T1) and the plant height gradually decreased along with the increased irrigation interval. Increase in plant height at high irrigation level might be due to higher moisture content of soil which resulted in increase in vegetative growth of the plants. 
Table 2: Mean comparison of plant height $(\mathrm{cm})$ of chilli (PC-1) at different irrigation interval

\begin{tabular}{lccccc}
\hline Treatments & 15 DATP & 30 DATP & 45 DATP & 60 DATP & 75 DATP \\
\hline T1 & $17.84^{\mathrm{a}}$ & $27.34^{\mathrm{a}}$ & $53.0^{\mathrm{a}}$ & $59.2^{\mathrm{a}}$ & $64.3^{\mathrm{a}}$ \\
$\mathrm{T} 2$ & $17.82^{\mathrm{a}}$ & $26.76^{\mathrm{a}}$ & $39.58^{\mathrm{b}}$ & $48.1^{\mathrm{ab}}$ & $50.0^{\mathrm{b}}$ \\
$\mathrm{T} 3$ & $17.7^{\mathrm{a}}$ & $25.58^{\mathrm{a}}$ & $34.48^{\mathrm{bc}}$ & $40.7^{\mathrm{c}}$ & $43.7^{\mathrm{b}}$ \\
$\mathrm{T} 4$ & $17.72^{\mathrm{a}}$ & $24.76^{\mathrm{a}}$ & $26.74^{\mathrm{c}}$ & $36.66^{\mathrm{c}}$ & $37.6^{\mathrm{b}}$ \\
F test & 0.979 & 0.345 & 0.000 & 0.007 & 0.003 \\
S.D. & 0.58 & 2.41 & 11.30 & 12.15 & 13.54 \\
S.E.mean \pm & 0.13 & 0.54 & 2.53 & 2.72 & 3.03 \\
\hline
\end{tabular}

Means with different letter(s) within the column are significantly different at $p=0.05$ level of probability.

The mean comparison of plant height at $5 \%$ significant level is given in Table 2, which shows that there were significant differences $(\mathrm{P}<0.05)$ in plant height between the treatments T1 with other treatments (45 DATP until harvest). There were no significant differences observed in mean plant height $(\mathrm{P}>0.05)$ from the transplanting stage to $30 \mathrm{DATP}$. The reason might be due to the plants were irrigated according to the irrigation interval after 15 DATP onwards, so that all the plants had received equal amount of water daily and they had utilized the available soil moisture even after the treatments were applied for the next 2 weeks. Therefore, initially they showed uniformity in the mean plant height. However, statistical analysis $(\mathrm{p}<0.05)$ showed that the change in irrigation interval had no significant effect on plant height except T1 at 75 DATP i.e., at the reproductive stage. Hence, according to the statistically analysed data (Table 2) it is proved that the plant height is significantly increased with the reduction in days of irrigation interval at vegetative growth stage.

Ertek et al. (2007) had stated that more the irrigation water applied, the higher the plant height was obtained and increase in the plant height increased the yield. Techawongstein $e t$ al., (1992) observed suppression of plant height due to water stress in chilli. Increase in plant height at high irrigation level might be due to proper moisture availability which resulted in increase in vegetative growth of the plants. Hence, the variation in plant height in the present study is also coinciding with the findings of Ertek et al. (2007); Techawongstein et al. (1992). 
Table 3: Correlation of plant height with other growth parameters

\begin{tabular}{lc}
\hline Growth Parameters & Correlation with plant height(r) \\
& \\
\hline Leaf area & 0.723 \\
Number of leaves per plant & 0.614 \\
Number of branches per plant & 0.728 \\
Shoot fresh weight & 0.751 \\
Shoot dry weight & 0.747 \\
Root fresh weight & 0.734 \\
Root dry weight & 0.512 \\
\hline
\end{tabular}

The Table 3 shows that, height of chilli plant showed positive correlation with other growth parameters such as, leaf area, number of leaves per plant, number of branches per plant, shoot biomass, root biomass etc. at 0.01 significance level.

\section{Leaf Area}

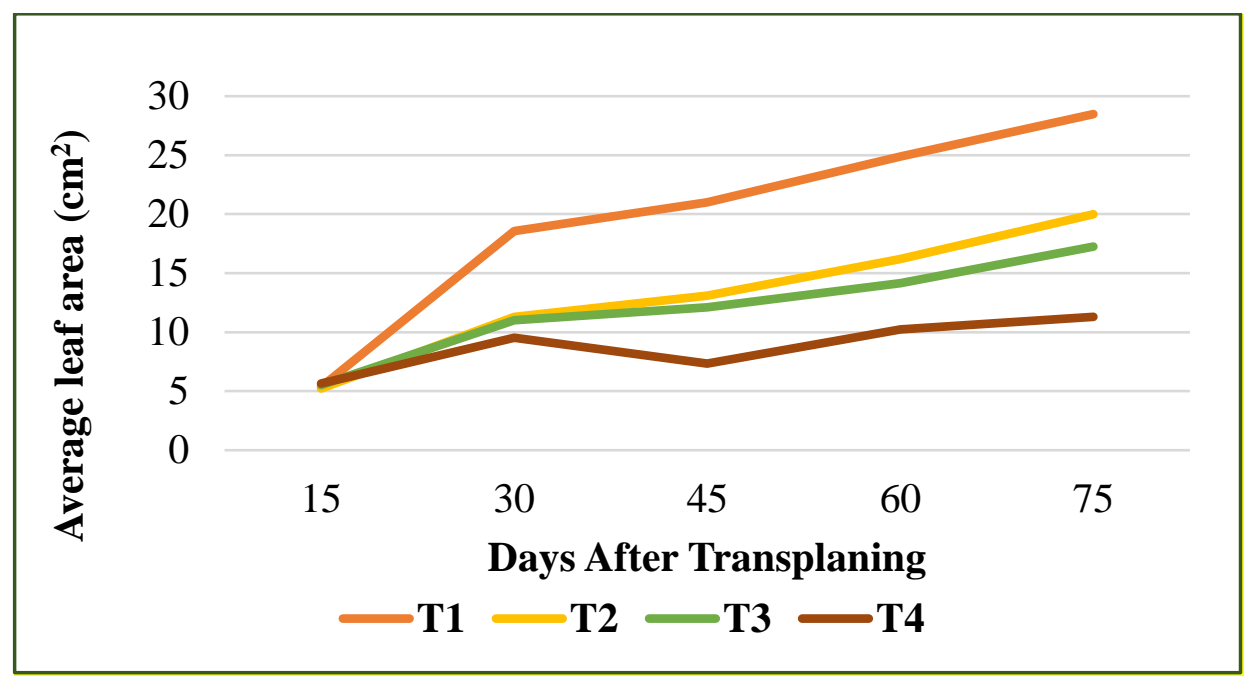

Figure 3: Effect of different irrigation intervals on mean leaf area $\left(\mathrm{cm}^{2}\right)$ of chilli (PC-1).

T1 treated plants had the highest leaf area as well as highest number of leaves/plant than other treatments. And, an instantaneous increase in leaf area could be observed at the initial crop growing stages and a gradual increase was observed at 30 DATP. The growth of leaf area was diminished at 30-45 DATP due to the chilli leaf curl disease and it was treated later therefore, the leaf area increased gradually after 45 DATP until harvest. 
Table 4: Mean comparison of leaf area $\left(\mathrm{cm}^{2}\right)$ of chilli (PC-1) at different irrigation interval

\begin{tabular}{lccccc}
\hline Treatments & 15 DATP & 30 DATP & 45 DATP & 60 DATP & 75 DATP \\
\hline T1 & $17.84^{\mathrm{a}}$ & $18.57^{\mathrm{a}}$ & $20.99^{\mathrm{a}}$ & $24.90^{\mathrm{a}}$ & $28.48^{\mathrm{a}}$ \\
$\mathrm{T} 2$ & $17.82^{\mathrm{a}}$ & $11.31^{\mathrm{b}}$ & $13.08^{\mathrm{b}}$ & $16.20^{\mathrm{b}}$ & $19.99^{\mathrm{b}}$ \\
$\mathrm{T} 3$ & $17.72^{\mathrm{a}}$ & $11.01^{\mathrm{b}}$ & $12.10^{\mathrm{b}}$ & $14.14^{\mathrm{bc}}$ & $17.26^{\mathrm{b}}$ \\
$\mathrm{T} 4$ & $17.70^{\mathrm{a}}$ & $9.52^{\mathrm{b}}$ & $7.33^{\mathrm{c}}$ & $10.23^{\mathrm{c}}$ & $11.30^{\mathrm{c}}$ \\
F test & Not sig. & Sig. & Sig. & Sig. & Sig. \\
S.D. & 0.58 & 4.37 & 5.88 & 6.32 & 6.83 \\
S.E.mean \pm & 0.13 & 0.98 & 1.31 & 1.41 & 1.53
\end{tabular}

Means with different letter( $s)$ in each column are significantly different at 0.05 level of probability.

It shows significant effect $(\mathrm{p}<0.05)$ on mean leaf area at $\mathrm{T} 1$ plot with other treatments plots and the difference was highest with $\mathrm{T} 4$ treated plot (Table 4). At 15 DATP there was no significant difference observed among the treatments as they all received equal quantity of water on daily basis. Rascio et al. (1990) also reported that water stress significantly reduced leaf area due to the reduced cell division. Lower leaf area and least number of leaves/chilli plant with drier treatment were also observed by Beese et al. (1982). Adeoye et al. (2014) has stated that the leaf area was also highest for the treatment with daily irrigation. The present study findings on the leaf area are in agreement with those findings.

\section{Number of branches per plant}

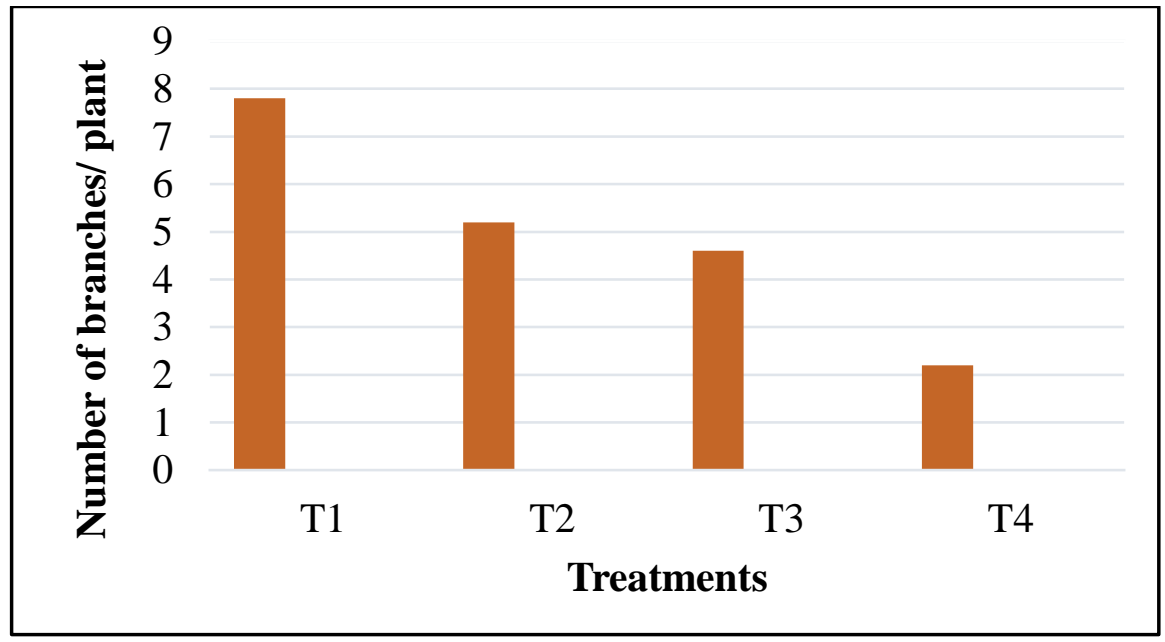

Figure 4: Effect of different irrigation intervals on average number of branches / plants of chilli

$$
\text { (PC-1) at } 75 \text { DATP }
$$

Number of branches was low in treatment 4 (at 7 days irrigation interval) by $28.8 \%$ from the control (T1). It is due to the insufficient water availability for proper vegetative growth. 
Table 5: Effect of different irrigation intervals on average number of branches/plants of chilli (PC1) at 75 DATP

\begin{tabular}{lc}
\hline Treatments & $\begin{array}{c}\text { No of Branches/ } \\
\text { plant }\end{array}$ \\
\hline $\mathrm{T} 1$ & $7.8^{\mathrm{a}}$ \\
$\mathrm{T} 2$ & $5.2^{\mathrm{b}}$ \\
$\mathrm{T} 3$ & $4.6^{\mathrm{b}}$ \\
$\mathrm{T} 4$ & $2.2^{\mathrm{c}}$ \\
F test & 0.000 \\
S.E.mean \pm & 0.478
\end{tabular}

Means with different letter(s) are significantly different at 0.05 level of probability.

According to the statistically analysed data on the average number of branches/plant (Table 5), there was no significant difference between the T2 and T3 (p>0.05). However highest number of branches/plants were found in $\mathrm{T} 1$ treated plots and there was a significant difference $(\mathrm{p}<0.05)$ observed between $\mathrm{T} 1$ with all the other treatments T2, T3 and T4

\section{Fresh weight and dry weight of shoot}

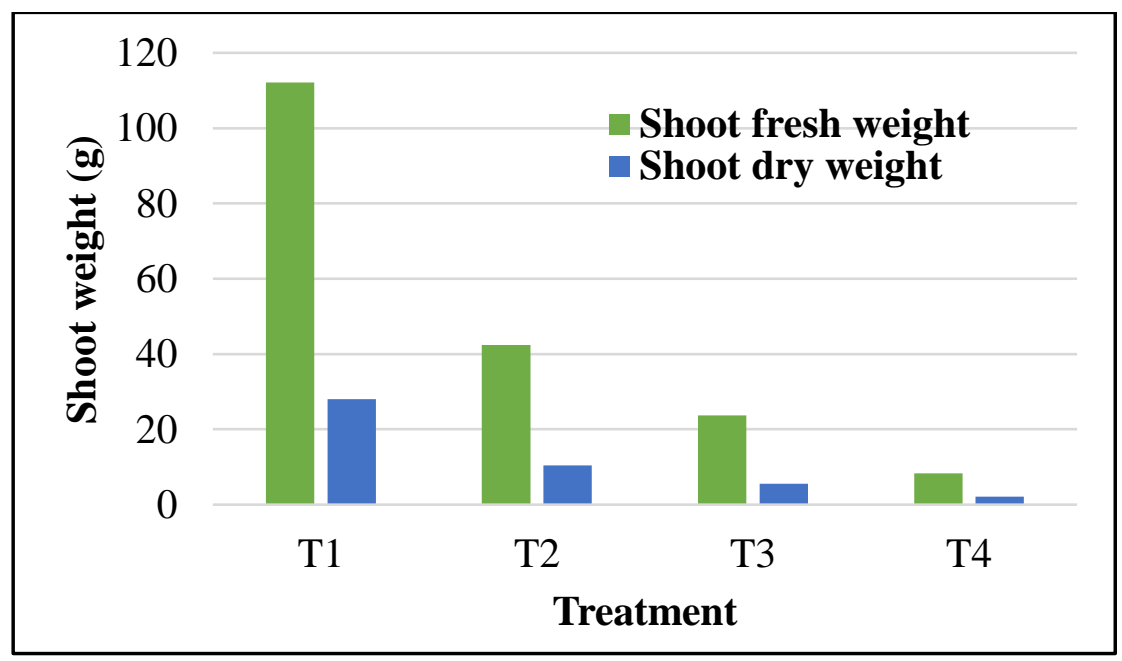

Figure 5: Effect of different irrigation intervals on mean shoot weight (g) of chilli (PC-1)

The shoot biomass was considerably reduced with the increase of irrigation interval and a higher difference was detected between the control of T1 and T4. This may be due to the reduction in leaf area of plants with the increase of irrigation interval, hence, photosynthesis is reduced and the accumulation of food in plants is lower. The shoot biomass showed positive correlation with leaf area at 0.01 significant level 
Table 6: Effect of different irrigation intervals on average shoot weight (g) of chilli (PC-1) at 75 DATP

\begin{tabular}{lcc}
\hline Treatments & Shoot fresh weight & Shoot dry weight \\
\hline T1 & $112.09^{\mathrm{a}}$ & $28.01^{\mathrm{a}}$ \\
$\mathrm{T} 2$ & $42.41^{\mathrm{b}}$ & $10.45^{\mathrm{b}}$ \\
T3 & $23.73^{\mathrm{c}}$ & $5.50^{\mathrm{c}}$ \\
T4 & $8.29^{\mathrm{d}}$ & $2.16^{\mathrm{d}}$ \\
F test & 0.000 & 0.000 \\
S.E.mean \pm & 9.134 & 2.294
\end{tabular}

Means with different letter(s) are significantly different at 0.05 level of probability.

Based on the table 6 , it is clear that there was significant difference in mean shoot fresh weight at 5\% significance level among the treatments. Similarly, mean dry weight also significantly differs among the treatments. At 75 DATP the highest fresh and dry biomass of shoot were obtained in control treatment of daily irrigation and followed by $\mathrm{T} 2, \mathrm{~T} 3$ and $\mathrm{T} 4$ irrigation intervals. The shoot and total dry weight reduction under longer irrigation interval in this study was in fact due to the reduction in values of growth-related parameters like leaf, stem and root of chilli plants. There was a noticeable reduction in fresh root mass as irrigation interval became longer (Table 7). This may be due to the restricted wetting pattern in longer irrigation interval, reduced crop canopy, closed stomata, and it consequently resulted in lower photosynthesis, which eventually culminated in lower storage. With these results it was clear that there is a direct relationship between shoot biomass with the quantity of water available for plant. It was also observed by Paul et al. (2013) that total plant biomass increased with reduced irrigation interval up to 5 days, due to more nutrients uptake and higher photosynthesis rates.

\section{Fresh and dry weight of roots}

Table 7: Mean comparison of root weight of chilli (PC-1) at 75 DATP among different irrigation interval

\begin{tabular}{lcc}
\hline Treatments & Root fresh weight & Root dry weight \\
\hline T1 & $12.58^{\mathrm{a}}$ & $3.85^{\mathrm{a}}$ \\
T2 & $7.95^{\mathrm{b}}$ & $3.61^{\mathrm{a}}$ \\
T3 & $7.95^{\mathrm{b}}$ & $3.41^{\mathrm{a}}$ \\
T4 & $5.16^{\mathrm{c}}$ & $2.41^{\mathrm{b}}$ \\
F test & 0.000 & 0.001 \\
S.E.mean \pm & 0.694 & 0.155 \\
\hline
\end{tabular}

Means with different letter(s) within the column are significantly different at 0.05 level of probability

The effect of different irrigation intervals on mean fresh and dry biomass of roots is shown in Table 7. The results showed that fresh biomass of roots was significantly varied 
$(\mathrm{p}<0.05)$ among the treatments in comparison to control (T1). It could be noticed that root mass detected in control was significantly greater than the other treatments. But the average dry biomass of roots is similar for all the treatments except T4. Therefore, dry root biomass was not affected by irrigation interval.

Table 8: Effect of different irrigation intervals on average Root/Shoot ratio of chilli (PC-1)

\begin{tabular}{lc}
\hline Treatments & Root/Shoot ratio \\
\hline T1 & $0.14^{\mathrm{d}}$ \\
T2 & $0.35^{\mathrm{c}}$ \\
T3 & $0.62^{\mathrm{b}}$ \\
T4 & $1.15^{\mathrm{a}}$ \\
F test & 0.000 \\
S.E.mean \pm & 0.201
\end{tabular}

Means with different letter(s) are significantly different at 0.05 level of probability

Root/shoot ratio is one of the growth parameters varied with water stress (Ozenc, 2008). According to the Table 8, the control treatment $\mathrm{T} 1 \mathrm{had}$ the lowest root/shoot ratio when compared with other treatments. Because the mean fresh shoot biomass was higher for T1 than that of other treatments. Zhang et al.
(2005) stated that plants grown under dry climate had lower stem length, transpiration and total biomass, but higher root/shoot ratio of plants. In the present study, the highest value of root/shoot ratio was observed for the plots treated with T4 and agreement with the findings of Zhang et al. (2005)

\section{Survival percentage}

Table 9: Effect of different irrigation intervals on survival percentage of chilli (PC-1)

\begin{tabular}{lc}
\hline Treatment & Survival \% \\
\hline T1 & $97.78^{\mathrm{a}}$ \\
T2 & $97.78^{\mathrm{a}}$ \\
$\mathrm{T} 3$ & $97.78^{\mathrm{a}}$ \\
$\mathrm{T} 4$ & $84.44^{\mathrm{b}}$ \\
F test & 0.002 \\
S.E.mean \pm & 1.709 \\
\hline
\end{tabular}

Means with different letter(s) are significantly different at 0.05 level of probability. 
The statistical analysed data of survival percentage at $5 \%$ significant level is given in Table 9. There was no significant difference in survival percentage among the treatments of T1, T2 and T3. However, significant difference was detected for the treatment of 7 days irrigation interval $\mathrm{T} 4$ with all the other treatments. The difference between the survival percentage of chilli plots treated with T4 and other treatments was $13.3 \%$. These results revealed that the chilli plants could withstand in longer irrigation intervals even it is cultivated in dry zone. Olalla and Valero (1994) also reported that survival percentage and plant height increased with decrease of irrigation interval and vice versa.

\section{Yield of chilli}

Table 10: Effect of different irrigation intervals on average yield of chilli (PC-1)

\begin{tabular}{lc}
\hline Treatments & Yield $(\mathbf{k g} / \mathbf{h a})$ \\
\hline T1 & $11623.9^{\mathrm{a}}$ \\
$\mathrm{T} 2$ & $4746.0^{\mathrm{b}}$ \\
$\mathrm{T} 3$ & $4452.0^{\mathrm{b}}$ \\
$\mathrm{T} 4$ & $1495.7^{\mathrm{c}}$ \\
F test & 0.000 \\
S.E.mean \pm & 883.5
\end{tabular}

Means with different letter(s) are significantly different at 0.05 level of probability.

According to the Table 10, the average marketable yields such as $11623.9 \mathrm{~kg} / \mathrm{ha}, 4746$ $\mathrm{kg} / \mathrm{ha}, 4452 \mathrm{~kg} / \mathrm{ha}$ and $1495.7 \mathrm{~kg} / \mathrm{ha}$ were obtained from the treatments T1, T2, T3 and $\mathrm{T} 4$ respectively. It can be seen from Table 10 that maximum yield of $11623 \mathrm{~kg} / \mathrm{ha}$ was harvested from control plot of $\mathrm{T} 1$ while the minimum yield $(1495 \mathrm{~kg} / \mathrm{ha})$ were recorded from plot T4. About $45.4 \%$ yield increase was noticed at $\mathrm{T} 1$ than plots irrigated with $\mathrm{T} 4$. This might be due to better survival percentage, greater number of pods per plant and total fruit weight per plant. There were no differences in yield was observed between treatment $\mathrm{T} 2$ and T3 at 5\% significant level ( $p>0.05)$. Similarly, in compare with $\mathrm{T} 3$, the chilli treated with $\mathrm{T} 1$ showed $32.1 \%$ of higher yield. It was also noticed that daily irrigation had significantly influenced the number of flowers per plant, number of pods per plant and ultimately the yield.

\section{CONCLUSION}

The growth traits such as height, leaf area and plant biomass significantly varied among different irrigation intervals. The amount of water use by the chilli plants was higher under well-watered treatments as compared to treatments with longer irrigation intervals. This study confirmed that the supplementary irrigation significantly affect the growth and the longer irrigation intervals of 7 days resulted in severe water stress leads to reduced growth of chilli. It was observed that all the studied parameters produced higher values in daily irrigated plots. While, irrigation has been recognized as a key production function for raising crop growth and productivity, effect of frequency and amount of irrigation as observed in this experiment produced statistically significant yield. The highest chilli yields can be 
achieved through daily irrigation in sandy soil of Batticaloa district, Sri Lanka. Though the irrigation at the crop requirement serves water with high water use efficiency, daily irrigation is produced superior growth characteristics and most suitable for sandy soils under dry weather conditions. The reason is due to the change in climatic factors the water requirement of the crop fluctuates frequently. Therefore, irrigation at 5 days intervals i.e. at the crop requirement with actual irrigation schedule is not suitable for chilli cultivation in sandy soil under dry weather condition.

\section{REFERENCES}

Adeoye, P. A., Adesiji, R. A., Oloruntade, A. J., and Njemanze, C. F. (2014). Effect of Irrigation Intervals on Growth and Yield of Bell Pepper (Capsicum annuum) in a Tropical Semi-arid Region. American Journal of Experimental Agriculture 4(5): 515-524.

Adhikari, K. R., and Shakya, S. M. (1995). Irrigation scheduling in vegetables for yield improvement and crop diversification. Inst. Of Agric. and Animal Sciences (1MS).

Amend, I. G. (2005). Crops. IrrigationRelated management factors. Irrigation guide. Chapter 06, Irrigation system design. NJ652.03.

Arulkirithas, N., Sugirtharan, M. and Irfeey, A.M.M. (2019). Suitability of groundwater for irrigation in Manmunai West Divisional secretariat area of Batticaloa District. AGRIEAST: Journal of Agricultural Sciences, 13(2), pp.17-26.

Beese, F., Horton, R. and Wierenga, P. J. (1982). Growth and yield response of chilli pepper to trickle irrigation. Agron. J. 74: 556561.
Department of Agriculture, Sri Lanka. (2019). Retrieved from https://www.doa.gov.lk/FCRDI/index.php/e n/crop/34-chilli.

Dorji, K., Behboudian, M. H., and ZegbeDominguez, J. A., (2005). Water relations, growth, yield, and fruit quality of hot pepper under deficit irrigation and partial rootzone drying. Scientia Horticulturae 104, 137-149.

Ertek, A., Gedik, I., Kucukyumuk, C., and Suat, S. (2007). Irrigation scheduling for green pepper (Capsicum annum L.) grown by field conditions by using class A pan evaporation value. American-Eurasian J. Agric. Environ. Sci., 2(4): 349-358.

Juan, I., Vílchez, Niehaus, K., Dowling, D.N., González-López, J. and Manzanera, M. (2018). Protection of Pepper Plants from Drought by Microbacterium sp. 3J1 by Modulation of the Plant's Glutamine and aketoglutarate Content: A Comparative Metabolomics Approach. Frontiers of Microbiology 9, 284.

Kei, K., Keijiro, O. and Kaliappa, K. (2008). Agriculture in developing countries.

Konstantinos, C., and Maria, B. (2015). The Effects of Irrigation and Drainage on Rural and Urban Landscapes. Sustainable water management in agriculture under climate change. Agriculture and Agricultural Science Procedia 4(2015) 88-9

Mateen, U.H.K., Tahir Hussain, C. and Nadia, S. (2005). Influence of different irrigation intervals on growth and yield of bell pepper (Capsicum annuum Grossum group). Research journal of Agriculture and Biological Sciences 1(2): 125-128.

Olalla, F. and Valero, J.A. (1994). Growth and production of bell pepper under different irrigation intervals. Research-SeriesArkansas-Agri. Expt. Station. 466: 92-95. (CAB Abstracts 1998/08-2000/04) 
Ozenc, B. D. (2008). Growth and transpiration of tomato seedlings grown in hazelnut husk under water deficit stress. Compost science \& utilization. 16(2): 125131.

Paul, J. C., Mishra, J. N., Pradhan, P. L., and Panigrahi, B. (2013). Effect of drip and surface irrigation on yield, water use efficiency of Capsicum annuum grown under mulch and non-mulch conditions in eastern coastal India. European J. Sus. Dev. 2013;2(1):99-108.

Rakha, M. K. A. (2018). Vegetable Improvement at World Vegetables from Genetic Resources to Commercialization. World Vegetable Center, AFSTA, Cairo, Egypt.

Rascio, A., Cedola, M., Topani, M., Flagella, Z. and Wittmer, G. (1990). Leaf morphology and water status changes in Tritieum durum under water stress. Physio plant 78, 462-467.
Robert, E., Donald, C. and Sneed, R. E. (1996). Soil, water and crop characteristics important to irrigation scheduling. Plant factors. NC State Extension Publications.

Techawongstein, S., Nawata, E. and Shigenga, S. (1992). Effect of water stress at various stages of plant development on growth and yield of chilli. Japanese Journal of Tropical Agriculture. Volume36 (1): 5157.

Udagedara, M.D. and Sugirtharan, M. (2018). Status of micro irrigation systems adopted for vegetable cultivation in Polonnaruwa district, Sri Lanka. AGRIEAST: 11(2):1-11.

Zhang, X., Wu, N, and Li, C. (2005). Physiological and growth responses of Populus davidiana ecotypes to different soil water contents. Journal of Arid Environment. 60(4): 567-579. 